\title{
Effect of Protein Stabilization on Charge State Distribution in Positive- and Negative-Ion Electrospray Ionization Mass Spectra
}

\author{
Stephen J. Watt, ${ }^{a}$ Margaret M. Sheil, ${ }^{\text {a }}$ Jennifer L. Beck, \\ Pavel Prosselkov, ${ }^{\mathrm{b}}$ Gottfried Otting, ${ }^{\mathrm{b}}$ and Nicholas E. Dixon ${ }^{\mathrm{b} *}$ \\ ${ }^{a}$ Chemistry Department, University of Wollongong, New South Wales, Australia \\ ${ }^{\mathrm{b}}$ Research School of Chemistry, Australian National University, Canberra, ACT, Australia
}

\begin{abstract}
Changes in protein conformation are thought to alter charge state distributions observed in electrospray ionization mass spectra (ESI-MS) of proteins. In most cases, this has been demonstrated by unfolding proteins through acidification of the solution. This methodology changes the properties of the solvent so that changes in the ESI-MS charge envelopes from conformational changes are difficult to separate from the effects of changing solvent on the ionization process. A novel strategy is presented enabling comparison of ESI mass spectra of a folded and partially unfolded protein of the same amino acid sequence subjected to the same experimental protocols and conditions. The N-terminal domain of the Escherichia coli DnaB protein was cyclized by in vivo formation of an amide bond between its $\mathrm{N}$ - and C-termini. The properties of this stabilized protein were compared with its linear counterpart. When the linear form was unfolded by decreasing $\mathrm{pH}$, a charge envelope at lower $\mathrm{m} / \mathrm{z}$ appeared consistent with the presence of a population of unfolded protein. This was observed in both positive-ion and negative-ion ESI mass spectra. Under the same conditions, this low $\mathrm{m} / \mathrm{z}$ envelope was not present in the ESI mass spectrum of the stable cyclized form. The effects of changing the desolvation temperature in the ionization source of the Q-TOF mass spectrometer were also investigated. Increasing the desolvation temperature had little effect on positive-ion ESI mass spectra, but in negative-ion spectra, a charge envelope at lower $\mathrm{m} / \mathrm{z}$ appeared, consistent with an increase in the abundance of unfolded protein molecules. (J Am Soc Mass Spectrom 2007, 18, 1605-1611) (c) 2007 American Society for Mass Spectrometry
\end{abstract}

C hanges in the charge state distribution (CSD) in the electrospray ionization (ESI) mass spectra of proteins are thought to relate to changes in protein conformation [1-6]. The majority of studies support that the maximum (positive) charge carried by an unfolded protein of mass up to approximately $40,000 \mathrm{Da}$ corresponds to the total number of basic residues $[7,8]$. For larger proteins and for nondenatured (native) proteins, the maximum number of charges observed is smaller and is thought to be determined by a combination of the accessibility of ionizable amino acid side chains near the surface of electrospray droplets, and the size and surface tension of the droplets as described by the Rayleigh limit [9-11]. The maximum charge $\left(Z_{R}\right)$ that can be carried by a folded protein has been calculated by considering the protein as a spherical ion with a size esti-

Address reprint requests to Dr. Jennifer Beck, University of Wollongong, Chemistry Department, Northfields Avenue, Wollongong, New South Wales 2522, Australia. E-mail: jbeck@uow.edu.au

* Also affiliated with the Chemistry Department, University of Wollongong, New South Wales, Australia. mated using the molecular weight (MW) of the protein, according to [10]

$$
\mathrm{Z}_{\mathrm{R}}=0.0778 \mathrm{~V} \mathrm{MW}
$$

Because protein secondary and tertiary structures are maintained by non-covalent forces, demonstrations of shifts in CSD as a result of protein unfolding have usually been achieved by altering solvent conditions $[1-3,5,12,13]$. Addition of acids or organic solvents exposes previously buried side chains by unfolding or partial unfolding of the protein.

It is generally accepted that ESI proceeds by a sequence of evaporation of charged droplets containing analyte and coulombic explosions [14 and references therein], with the final stages of ion formation explained by the ion evaporation [15] or charged-residue models [16]. The latter model has been proposed to best represent the process for protein ions [10, 17]. In the case of positive-ion ESI mass spectra, protons from the solvent buffers are transferred to accessible proton acceptor sites on the protein. Negative ions are formed when protons from the protein are transferred to the 
solvent. The extent of proton transfer depends not only on the accessibility of ionizable sites, but also on the relative gas-phase basicities of these sites and of the solvent [18-20]. Changes in solvent composition also affect the rate of evaporation of droplets, their surface tension, and possibly the orientation of the analyte within the droplet [14 and references therein]. Therefore, the effects of unfolding on the CSD in ESI mass spectra are difficult to extricate from the effects of changing solvents.

There have been a few studies that supported that the charge state distribution observed in positive-ion ESI mass spectra of proteins changes depending on the shape (compactness) of the protein in the absence of significant changes in solvent. Simmons and Konermann [21] mixed unfolded, heme-free myoglobin with heme under conditions where intact myoglobin remained folded and infused the mixture directly into an ESI mass spectrometer. Several conformational forms of the protein were evident as the heme bound to the protein as revealed by the presence of different charge state distributions in the spectra. Smith and coworkers [22] showed that reduction of the disulfide bonds in lysozyme by treatment with dithiothreitol (DTT) caused a shift to higher charge states. The reduction of the disulfide bonds results in at least partial unfolding. In this case, the folded and unfolded lysozyme were sampled from $5 \%$ acetic acid, although the solution containing unfolded lysozyme also contained DTT. Changes in CSD have also been observed in negativeion ESI mass spectra when proteins undergo changes in conformation. For example, when the acidic protein calmodulin adopts a more compact conformation as it binds calcium, negative ions carrying fewer charges are observed in the ESI mass spectra [23, 24]. However, interpretation of this observation is complicated somewhat by the binding of positively charged calcium to acidic residues on the protein.

Here we report a novel experimental design for demonstrating that proteins carry different numbers of charges as shown in ESI mass spectra depending on their shape (compactness) and in the absence of complicating factors such as changing solvents or the addition of ligands that might mask or add charges. ESI mass spectra of a protein were compared with spectra of a cyclized version of the same protein. The Nterminal domain (residues 24-136) of the DnaB helicase from Escherichia coli (DnaB-N) was cyclized by introducing an amide bond between the $\mathrm{N}$ - and C-termini. A nine amino acid linker (TRESGSIEF) was added to the protein to ensure that no conformational strain was placed on the structure, and the residue F102 was changed to glutamic acid to prevent dimerization of the protein $[25,26]$. Figure 1 shows a schematic representation of the structures of the cyclized [cz-DnaB$\mathrm{N}(\mathrm{F} 102 \mathrm{E})$; Figure 1a] and linear versions [lin-DnaB$\mathrm{N}(\mathrm{F} 102 \mathrm{E})$; Figure 1b] of the protein. As determined in solution by NMR, the structure of DnaB-N(F102E) was unperturbed by cyclization and the linker residues were highly mobile, as expected for a flexible peptide seg-
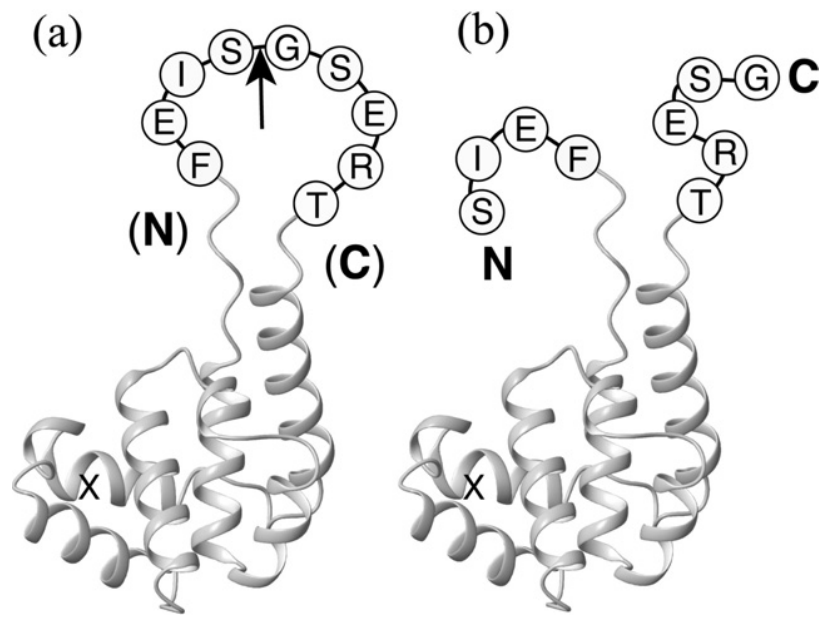

Figure 1. Ribbon representation of the structures of cz-DnaB$\mathrm{N}(\mathrm{F} 102 \mathrm{E})^{\circ}$ and $^{\circ}$ lin-DnaB-N(F102E $)^{\circ}\left[25,{ }^{\circ} 26\right]^{\circ}$ showing $^{\circ}$ the ${ }^{\circ}$ sequence $^{\circ}$ of the nine amino acid linker. The cross marks the position of the F102E mutation. (a) cz-DnaB-N(F102E). The arrow identifies the peptide bond between the $\mathrm{N}$ and $\mathrm{C}$ termini. (b) lin-DnaB-N(F102E).

ment that assumes multiple backbone conformations $[25,26]$. The two proteins have the same amino acid sequence ( $\mathrm{pI} \simeq 4.7$ ), including $10 \mathrm{Arg}, 2$ Lys, 3 His, 13 Glu, and 8 Asp residues, but differ by the mass of a water molecule $(18 \mathrm{Da})$. Cyclization of proteins has been used as a tool to study the stabilization gained by reducing the conformational entropy of the circularized protein in its denatured state [25-30]. For these studies to be valid, the $\mathrm{N}$ - and C-termini of the linear protein must be close in space so that cyclization does not alter the core structure [26]. This requirement is met by DnaB-N. We have shown that the cyclized protein is more resistant to thermal denaturation $[28]^{\circ}$ and, ${ }^{\circ}$ by using circular dichroism (CD) spectroscopy, that the difference in free energy of unfolding $(\Delta \Delta G)$ between lin- and cz-DnaB-N(F102E) at neutral $\mathrm{pH}$ at $10^{\circ} \mathrm{C}$ is 2.3 $( \pm 0.5) \mathrm{kcal}^{\circ} \mathrm{mol}^{-1}{ }^{\circ}[26]$. These experiments ${ }^{\circ}$ also indicated that the linear protein is in equilibrium with a few percent of unfolded conformation. When the unfolding rates of the linear and cyclized proteins were compared by measuring hydrogen-deuterium exchange of amide protons using ESI-MS and NMR, the rates were ten times ${ }^{\circ}$ faster ${ }^{\circ}$ for $^{\circ}$ the $e^{\circ}$ linear ${ }^{\circ}$ protein $^{\circ}[26]$.

The higher stability of the cyclized protein can therefore be exploited to study the effect of protein shape/ folding on the CSD in ESI mass spectra. In the present work, positive- and negative-ion ESI mass spectra of czand lin-DnaB-N(F102E) at $\mathrm{pH} 7.6$ were compared. The effects of altering desolvation temperature in the ionization source were also investigated. The results suggested that negative-ion ESI mass spectra are more sensitive for detecting unfolding than positive-ion spectra. These results are discussed in the context of other studies that have compared positive- and negative-ion mass $^{\circ}$ spectra $^{\circ}$ of $^{\circ}$ proteins $^{\circ}\left[12,{ }^{\circ} 24,, 31\right]$. 


\section{Experimental}

\section{Proteins}

DnaB-N was cyclized in vivo by use of a split miniintein from Synechoscystis sp. PCC6803 DnaB constructed $^{\circ}$ for $^{\circ}$ maximum $^{\circ}$ codon $^{\circ}$ usage $^{\circ}$ in $^{\circ}$ E. coli [28]. Preparation of plasmid constructs that direct production of lin- and cz-DnaB-N(F102E) proteins containing the nine amino acid linker and the F102E mutation and methods for purification of the proteins were as described ${ }^{\circ}[26] .{ }^{\circ}$ Before ${ }^{\circ} \mathrm{ESI}^{\circ} \mathrm{mass}^{\circ}$ spectrometry ${ }^{\circ}$ or $^{\circ} \mathrm{CD}^{\circ}$ spectroscopy, protein samples $(\sim 300 \mu \mathrm{L})$ were dialyzed at $4{ }^{\circ} \mathrm{C}$ against three changes of $2 \mathrm{~L}$ of $10 \mathrm{mM}$ ammonium acetate solution adjusted to $\mathrm{pH} 7.6$, then against $2 \mathrm{~L}$ of $10 \mathrm{mM}$ ammonium acetate adjusted to the $\mathrm{pH}$ required for each experiment. Formic acid was used when required to adjust the $\mathrm{pH}$ to 2.0. After dialysis, protein samples were concentrated at $4{ }^{\circ} \mathrm{C}$ using Microcon centrifugal filters (Millipore, Bedford, MA, USA; molecular weight cutoff $10 \mathrm{kDa}$ ). The protein concentrations were evaluated by measurement of the UV absorbance at $280 \mathrm{~nm}$ and using a molar absorption coefficient $\left(\varepsilon_{280}\right)$ of ${ }^{\circ} 9530^{\circ} \mathrm{M}^{-1^{\circ}} \mathrm{cm}^{-1^{\circ}}[28]^{\circ}{ }^{\circ}$ The $^{\circ}$ final $^{\circ}$ concentrations ${ }^{\circ}$ of protein stocks were $15-50 \mu \mathrm{M}$. The molecular masses of cz- and lin-DnaB-N(F102E) calculated from their sequences are 13,541 and $13,559 \mathrm{Da}$, respectively.

\section{ESI Mass Spectrometry of cz- and lin-DnaB-N(F102E)}

After dialysis and concentration, protein stock solutions were diluted to $10 \mu \mathrm{M}$ using the solution from the final dialysate and injected directly into the ionization source of a Micromass (now Waters, Wyntheshawe, UK) Qtof2 mass spectrometer with a Z-spray probe using a Harvard Model 22 syringe pump (Natick, MA, USA) at a flow rate of $10 \mu \mathrm{L} \mathrm{min}{ }^{-1}$. Negative- and positive-ion ESI mass spectra were acquired using a probe tip potential of $2600 \mathrm{~V}$, a cone voltage of $35 \mathrm{~V}$, and the source block and desolvation temperatures were $40^{\circ} \mathrm{C}$ unless stated otherwise. The transport and aperture were set to 2.0 and 13.0, respectively. In most experiments, spectra were acquired over the range $m / z$ 500-3000. Typically, 20 to 30 acquisitions were summed to obtain representative spectra. The data were calibrated against a standard CsI solution $(750 \mu \mathrm{M})$ over the same $\mathrm{m} / \mathrm{z}$ range.

\section{Spectroscopy}

Protein solutions for CD spectroscopy were prepared by dilution of dialyzed proteins to $23 \mu \mathrm{M}$ using the solution from the final dialysate. CD spectra (190-250 $\mathrm{nm}$ ) were collected using a JASCO J-810 spectropolarimeter with a bandwidth of $0.5 \mathrm{~nm}$ in $1 \mathrm{~mm}$ pathlength cell at $23^{\circ} \mathrm{C}$. Six spectra were summed and spectra of the solutions from the final dialysates were subtracted to give the final spectrum for each sample.

\section{Results and Discussion}

The tertiary structures of both lin-DnaB-N(F102E) and Cz-DnaB-N(F102E) are expected to remain intact at $\mathrm{pH}$ 7.6926]. Therefore, if the electrospray process itself does not disrupt non-covalent interactions within the protein structure, then the $\mathrm{ESI}^{\circ} \mathrm{mass}^{\circ}$ spectra $^{\circ}$ of ${ }^{\circ}$ these ${ }^{\circ}$ proteins would ${ }^{\circ}$ be ${ }^{\circ}$ expected ${ }^{\circ}$ to ${ }^{\circ}$ be ${ }^{\circ}$ the ${ }^{\circ}$ same..$^{\circ}$ Figure ${ }^{\circ} 2^{\circ}$ shows ${ }^{\circ}$ the positive-ion ${ }^{\circ}$ ESI mass spectra of lin- and cz-DnaB$\mathrm{N}$ (F102E) sprayed from ammonium acetate at $\mathrm{pH} 7.6$ applying desolvation temperatures of 40 and $^{\circ} 240^{\circ} \mathrm{C}$. The spectra of ${ }^{\circ}$ inear ${ }^{\circ}$ and $^{\circ}{ }^{\circ}$ cyclized ${ }^{\circ}$ forms at $40^{\circ}{ }^{\circ} \mathrm{C}^{\circ}$ (Figure $2 a^{\circ}$ and $c$, respectively) were very similar. Because the cyclized protein is more stable to unfolding, this suggests that both forms of the protein retained their structure during the ionization process. The $[\mathrm{M}+7 \mathrm{H}]^{7+}$ ions [m/z 1938.0 for lin-DnaB-N(F102E) and 1935.4 for cz-DnaB-N(F102E)] were the most abundant, with the $[\mathrm{M}+8 \mathrm{H}]^{8+}[\mathrm{m} / \mathrm{z} 1695.9$ for lin-DnaB-N(F102E) and 1693.6 for cz-DnaB-N(F102E)] ions also of substantial, but lower, abundance. The $[\mathrm{M}+9 \mathrm{H}]^{9+}$ ions were present at very low abundance. Ions corresponding to a dimer of DnaB-N(F102E) were of very weak intensity; the $[2 \mathrm{M}+11 \mathrm{H}]^{11+}$ ion is marked on the figure. This indicates that the F102E mutations efficiently, but possibly incompletely, disrupt the dimer interface observed in the ${ }^{\circ}$ wild-type ${ }^{\circ}$ protein $^{\circ}\left[25,{ }^{\circ} 32\right] . .^{\circ}$ Spectra ${ }^{\circ}$ of ${ }^{\circ}$ lin-DnaB$\mathrm{N}(\mathrm{F} 102 \mathrm{E})^{\circ}$ shown in Figure ${ }^{\circ} 2 a^{\circ}$ and $^{\circ} \mathrm{b}^{\circ}$ also showed very small amounts of ions at lower $\mathrm{m} / \mathrm{z}$, consistent with a small population of the protein being in the unfolded state at equilibrium (see below); this is consistent with the previous observations by other techniques [26], and suggests that positive-ion ESI-MS is accurately sampling the composition of the solution. Using eq 1

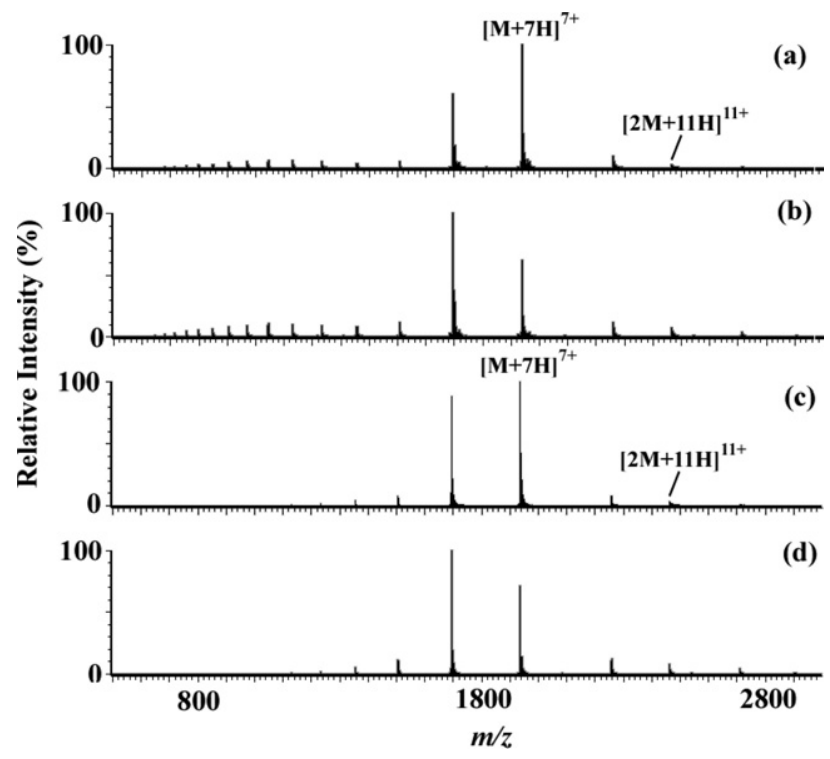

Figure 2. Positive-ion ESI mass spectra of lin-DnaB-N(F102E) and cz-DnaB-N(F102E) sprayed from $10 \mathrm{mM}$ ammonium acetate, $\mathrm{pH}$ 7.6, using desolvation temperatures of 40 or $240^{\circ} \mathrm{C}$. (a) lin-DnaB$\mathrm{N}$ (F102E) at $40{ }^{\circ} \mathrm{C}$; (b) lin-DnaB-N(F102E) at $240{ }^{\circ} \mathrm{C}$; (c) cz-DnaB$\mathrm{N}(\mathrm{F} 102 \mathrm{E})$ at $40^{\circ} \mathrm{C} ;(\mathbf{d}) \mathrm{Cz}-\mathrm{DnaB}-\mathrm{N}(\mathrm{F} 102 \mathrm{E})$ at $240^{\circ} \mathrm{C}$. 
(above), the maximum positive (or negative) charge expected for folded lin- and cz-DnaB-N(F102E) is nine. The results are in reasonable agreement with this. The positive-ion ESI mass spectra of lin- and cz-DnaB$\mathrm{N}(\mathrm{F} 102 \mathrm{E})$ obtained using a desolvation temperature of $240^{\circ} \mathrm{C}^{\circ}$ (Figure $2 \mathrm{~b}^{\circ}$ and ${ }^{\circ} \mathrm{d}$, respectively) ${ }^{\circ}$ were ${ }^{\circ}$ very ${ }^{\circ}$ similar to those obtained at $40{ }^{\circ} \mathrm{C}$ except that, in each case, the $[\mathrm{M}+8 \mathrm{H}]^{8+}$ ion was of greater abundance than the $[\mathrm{M}+7 \mathrm{H}]^{7+}$ ion. This may reflect the expected slightly higher ${ }^{9}$ ate ${ }^{\circ}{ }^{\circ}$ evaporation [33]. Overall, the ${ }^{\circ}$ similarity ${ }^{\circ}$ of the spectra at the two desolvation temperatures suggests that increasing the temperature in the ionization source did not denature the protein to a great extent. It should be remembered that the temperature of the desolvation gas is not the temperature experienced by the protein. There are numerous interrelated factors to consider, such as the rate of heat transfer to droplets, the rate of desolvation of the solvent, the decrease in temperature as a result of evaporation, and the lifetime of $^{\circ}$ the $^{\circ}$ droplets $^{\circ}$ in $^{\circ}$ the $e^{\circ}$ ionization ${ }^{\circ}$ source ${ }^{\circ}[33]$.

Positive-ion ESI mass spectra of the linear and cyclized proteins electrosprayed from $10 \mathrm{mM}$ ammonium acetate solutions where the $\mathrm{pH}$ had been adjusted to 2.0 and the desolvation temperature was $40^{\circ} \mathrm{C}$ are shown in $^{\circ}$ Figure $^{\circ} 3$. $^{\circ}$ Figure $^{\circ} 3 \mathrm{a}^{\circ}$ shows $^{\circ}$ the $^{\circ}$ ESI $^{\circ}$ mass $^{\circ}$ spectrum $^{\circ}$ of lin-DnaB-N(F102E) sprayed from this solution. The spectrum reveals two charge envelopes: the envelope at higher $\mathrm{m} / \mathrm{z}$ (fewer charges) is representative of the folded protein as observed when it was sprayed from $10^{\circ} \mathrm{mM}^{\circ}$ ammonium $^{\circ}$ acetate $^{\circ}$ at $^{\circ} \mathrm{pH}^{\circ} 7.6^{\circ}$ (Figure $^{\circ} 2 \mathrm{a}$ ), whereas the most abundant ion of the second charge envelope is $[\mathrm{M}+13 \mathrm{H}]^{13+}(\mathrm{m} / \mathrm{z} 1044.0)$, with a maximum charge of $16+$ observed (consistent with the presence of 15 basic residues in the protein, including the $\mathrm{N}$ terminus). This is not unexpected, given that changing the overall charge of a protein from negative to positive or vice versa by changing $\mathrm{pH}$ across the isolectric point usually causes denaturation, and changing the interactions between the buried residues Glu33 and His64 in DnaB- $\mathrm{N}^{\circ}[25]^{\circ}$ by $^{\circ}$ protonation ${ }^{\circ}$ or $^{\circ}$ deprotonation ${ }^{\circ}$ is ${ }^{\circ}$ likely to trigger at least partial unfolding of the tertiary structure. ${ }^{\circ}$ Figure $^{\circ} 3 b^{\circ}$ shows $^{\circ}$ the $^{\circ}$ positive-ion $^{\circ} \mathrm{ESI}^{\circ}$ mass

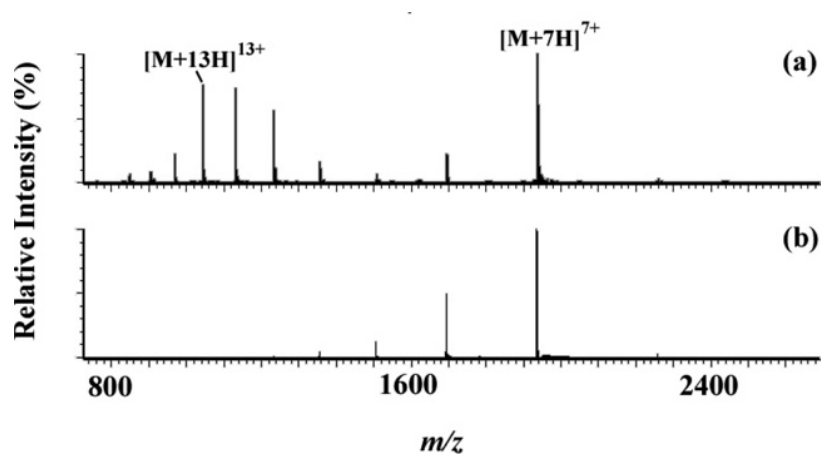

Figure 3. Positive-ion ESI mass spectra of lin-DnaB-N(F102E) and cz-DnaB-N(F102E) sprayed from $10 \mathrm{mM}$ ammonium acetate, $\mathrm{pH} 2.0$, using a desolvation temperature of $40^{\circ} \mathrm{C}$. (a) lin-DnaBN(F102E); (b) cz-DnaB-N(F102E). spectrum of cz-DnaB-N(F102E) sprayed from the same solution under the same conditions. In this case, only one charge envelope was observed and the spectrum was $^{\circ}$ similar $^{\circ}$ to $^{\circ}$ that $^{\circ}$ when $^{\circ}$ the ${ }^{\circ} \mathrm{pH}^{\circ}$ was $^{\circ} 7.6^{\circ}$ (Figure ${ }^{\circ} 2 \mathrm{c}$ ). This suggests that, although some of the non-covalent interactions might be changed at $\mathrm{pH}$ 2.0, the covalent closing of the circular protein maintains it in a structural form that allows it to carry only seven to nine positive charges (the $[\mathrm{M}+10 \mathrm{H}]^{10+}$ ion was present at very low abundance, roughly $3 \%$ of the $[\mathrm{M}+7 \mathrm{H}]^{7+}$ ion). These observations are consistent with cyclization of the protein maintaining it in a shape that allows only seven or eight residues to be in contact with the surface of the droplet $^{\circ}$ during ${ }^{\circ}$ evaporation. ${ }^{\circ}$ The $^{\circ}$ similarity $^{\circ}$ of ${ }^{\circ}$ Figure $^{\circ} \mathrm{C}$ [cz-DnaB-N(F102E) ${ }^{\circ}$ at $\left.^{\circ} \mathrm{pH}^{\circ} 7.6\right]^{\circ}$ and ${ }^{\circ}$ Figure $3 \mathrm{~b}^{\circ}[\mathrm{cz}-\mathrm{DnaB}-$ $\mathrm{N}(\mathrm{F} 102 \mathrm{E})$ at $\mathrm{pH} 2.0]$ is supportive of estimates of maximum charge based on eq 1 and demonstrates that this stabilized protein presents the same number of positive charges irrespective of the $\mathrm{pH}$ of the solvent.

The structures of lin- and cz-DnaB-N(F102E) were examined by $C D$ spectroscopy in the same solutions used $^{\circ}$ for $^{\circ}$ ESI-MS $^{\circ}\left(\right.$ Figure $\left.^{\circ} 4\right) .^{\circ}$ At $^{\circ} \mathrm{pH}^{\circ} 7.6,{ }^{\circ}$ both $^{\circ}$ proteins gave $^{\circ}$ spectra $^{\circ}$ typical $^{\circ}$ of $^{\circ} \alpha$-helical ${ }^{\circ}$ proteins $^{\circ}\left(\right.$ Figure $^{\circ} 1$ ), with the intensity of the CD being slightly higher $(\sim 6 \%$ at $222 \mathrm{~nm}$ ) for the cyclized than for the linear form (Figure $\left.{ }^{\circ} 4\right),{ }^{\circ}$ again $^{\circ}$ consistent $^{\circ}$ with $^{\circ} \mathrm{a}^{\circ}$ small $^{\circ}$ equilibrium population of unfolded protein being present in the lin-DnaB-N(F102E) sample. At pH 2, CD bands in the spectra characteristic of $\alpha$-helices were still present, but were reduced in intensity, consistent with a general reduction in $\alpha$-helical content. Assuming spectra contain contributions from only helical and random coil structures, as might be predicted from earlier studies of denaturation ${ }^{\circ}$ of $^{\circ}$ DnaB- $\mathrm{N}^{\circ}$ proteins ${ }^{\circ}$ by $^{\circ}$ urea $^{\circ}$ and ${ }^{\circ}$ heat ${ }^{\circ}[25$, 26], ${ }^{\circ}$ then ${ }^{\circ}$ the ${ }^{\circ} \mathrm{CD}^{\circ}$ at $^{\circ} 222^{\circ} \mathrm{nm}^{\circ}$ enables $^{\circ}$ us $^{\circ}$ to $^{\circ}$ calculate $^{\circ}$ the helical content of the linear and cyclized proteins at $\mathrm{pH}$ 2 to be about 40 and $60 \%$, respectively, of that of the fully folded protein at $\mathrm{pH}$ 7.6. The positive-ion ESI-MS data ${ }^{\circ}{ }^{\circ}$ Figure $^{\circ} 3 \mathrm{~b}^{\circ}$ suggest ${ }^{\circ}$ that ${ }^{\circ} \mathrm{Cz}-\mathrm{DnaB}-\mathrm{N}(\mathrm{F} 102 \mathrm{E}){ }^{\circ}$ exists at $\mathrm{pH} 2$ as a single species of a relatively compact structure, which therefore has about $40 \%$ less helical secondary structure than the native protein. The decrease in helicity may be the result of local unfolding caused by protonation of the buried His64 side chain. If we were further to assume that the CD of lin-DnaB$\mathrm{N}(\mathrm{F} 102 \mathrm{E})$ at $\mathrm{pH} 2$ reflects an equilibrium between this structure and a random coil acid-denatured state, then we predict that about a third of the linear protein exists in the unfolded state under these conditions. This analysis is qualitatively consistent with the ESI-MS data in $^{\circ}$ Figure $^{\circ} 3 a^{\circ}$, suggesting $^{\circ}$ that $^{\circ}$ about $^{\circ}$ half $^{\circ}$ of ${ }^{\circ}$ lin-DnaB$\mathrm{N}(\mathrm{F} 102 \mathrm{E})$ molecules are unfolded at $\mathrm{pH} 2$.

The detection of positive ions in ESI mass spectra for proteins with acidic isoelectric points [as observed here at $\mathrm{pH} 7.6$ for lin- and cz-DnaB-N(F102E)] or negative ions for proteins with basic isoelectric points, highlights that there are many factors to be considered other than the charges that occur in solution for prediction of charge state distributions of proteins in ESI mass spec- 


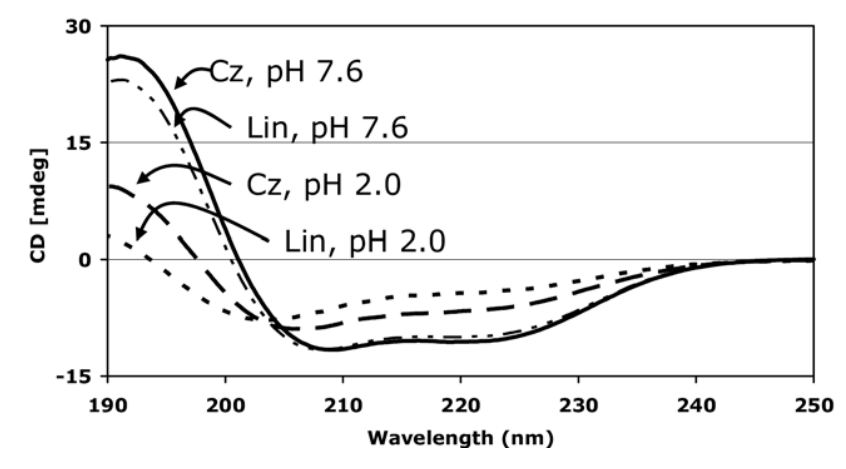

Figure 4. $C D$ spectra of lin-DnaB-N(F102E) and cz-DnaB$\mathrm{N}$ (F102E) in $10 \mathrm{mM}$ ammonium acetate at $\mathrm{pH} 7.6$ or 2.0. The protein concentration was $23 \mu \mathrm{M}$ in each case.

tra. Equation 1 applies only to folded proteins because it considers the maximum number (Rayleigh limit) of charges (negative or positive) that can be accommodated on a spherical droplet as presented by a globular protein. This estimate will be best for folded proteins that assume a roughly spherical shape and when sufficient numbers of positive and negative charges are accessible on the surface. In this case, the size of the spherical droplet (and thus the Rayleigh limit) is related to the molecular weight of the protein. If structures exist where charges of either polarity are substantially less accessible to the surface of the droplet, then the Rayleigh charge will differ from the calculated value. Nestayy and 'Suter[11]'showed ${ }^{\text {there }}$ 'was good agreement for many proteins between the calculated maximal Rayleigh charge and the maximum charge observed in ESI mass spectra acquired under non-denaturing conditions. Significant discrepancies, however, were observed in negative-ion mass spectra of some proteins including calmodulin, as also observed in our laboratory ${ }^{\circ}\left[11,{ }^{\circ} 24\right] .{ }^{\circ}$ Such $^{\circ}$ discrepancies $^{\circ}$ may $^{\circ}$ arise $^{\circ}$ from ${ }^{\circ}$ the different volatility of buffers used when acquiring positive- ${ }^{\circ}$ versus $^{\circ}$ negative-ion ${ }^{\circ} \mathrm{ESI}^{\circ}$ mass $^{\circ}$ spectra $^{\circ}[10]$. Different buffers might also alter protein conformations. The stability of cz-DnaB-N(F102E) compared to its linear counterpart enabled the comparison of spectra of two different conformational states (folded and unfolded) of the same protein in the same solvent. Further, the proteins were used to assess the impact of protein conformation on negative- and positive-ion ESI mass spectra in the same solvent.

Figure $^{\circ} 5^{\circ}$ shows $^{\circ}$ the ${ }^{\circ}$ negative-ion ${ }^{\circ}$ ESI $^{\circ}$ mass $^{\circ}$ spectra ${ }^{\circ}$ of lin- and cz-DnaB-N(F102E) sprayed from $10 \mathrm{mM}$ ammonium acetate, $\mathrm{pH} 7.6$ (the same samples as for the positive-ion ESI mass spectra) using desolvation temperatures of 40 and $240{ }^{\circ} \mathrm{C}$. The negative-ion spectrum of cz-DnaB-N(F102E) obtained with a desolvation temperature of $40^{\circ} \mathrm{C}$ is similar to the positive-ion spectrum and $^{\circ}$ is ${ }^{\circ}$ shown $^{\circ}$ in $^{\circ}$ Figure $^{\circ} 5 c^{\circ}$ The $^{\circ}$ ion $^{\circ}$ carrying $^{\circ}$ seven charges is the most abundant, as observed in the positive-ion ${ }^{\circ}$ spectrum $^{\circ}\left(\right.$ Figure $\left.^{\circ} 2 \mathrm{c}\right) .^{\circ}{ }^{\circ} \mathrm{The}^{\circ}[\mathrm{M}-8 \mathrm{H}]^{8-{ }^{\circ}}$ and $[\mathrm{M}-9 \mathrm{H}]^{9-}$ ions are present at low abundance: 26 and $4.4 \%$ of the abundance of the $[\mathrm{M}-7 \mathrm{H}]^{7-}$ ion, respec- tively. This is in agreement with the maximum charge of $9-$ calculated from eq 1 . The $[\mathrm{M}-6 \mathrm{H}]^{6-}$ ion is present at $39 \%$ of the abundance of the $[\mathrm{M}-7 \mathrm{H}]^{7-}$ ion. When the desolvation temperature was increased to $240^{\circ} \mathrm{C}^{\circ}$ (Figure ${ }^{\circ} \mathrm{d}$ ), ${ }^{\text {t the }}$ more $^{\circ}$ highly $^{\circ} \mathrm{Charged}^{\circ}$ ions ${ }^{\circ}\left(8-{ }^{\circ}\right.$ to 11-) increased in abundance, but were still less abundant than the 7- and 6-ions. This is in contrast to the positive-ion spectra where the increase in desolvation temperature had a smaller effect on the mass spectrum (compare ${ }^{\circ}$ Figure ${ }^{\circ} 2 \mathrm{c}^{\circ}$ and ${ }^{\circ} \mathrm{d}$ ).

The negative-ion spectrum of lin-DnaB-N(F102E) at ${ }^{\circ} \mathrm{pH}^{\circ} 7.6^{\circ}$ and $^{\circ} 40^{\circ} \mathrm{C}^{\circ}\left(\text { Figure }^{\circ} 5 \mathrm{a}\right)^{\circ}$ is ${ }^{\circ}$ similar $^{\circ}$ to ${ }^{\circ}$ that ${ }^{\circ}$ of cz-DnaB-N(F102E) ${ }^{\circ}$ (Figure $^{\circ} 5 \mathrm{c}$ ), ${ }^{\circ}$ where $^{\circ}$ the ${ }^{\circ}$ major charge envelope represents the folded protein and the $[\mathrm{M}-7 \mathrm{H}]^{7-}$ ion predominates, although a second less abundant charge envelope centered around the $[\mathrm{M}-14 \mathrm{H}]^{14-}$ ion was also present. This suggests, once again, that a small population of the protein molecules were ${ }^{\circ}$ unfolded ${ }^{\circ}{ }^{\circ}{ }^{\circ}$ solution $^{\circ}[26]^{\circ}$. Increasing ${ }^{\circ}$ the ${ }^{\circ}$ desolvation temperature to $240^{\circ} \mathrm{C}$ increased the abundance of the ions in this lower $\mathrm{m} / \mathrm{z}$ (more highly charged) envelope, suggesting that these experimental conditions promoted unfolding of the protein, although denaturation was still incomplete. Previously, Mirza and Chait [33] ${ }^{\circ}$ observed ${ }^{\circ}$ that ${ }^{\circ}$ application ${ }^{\circ}$ of ${ }^{\circ}$ heat ${ }^{\circ}$ to ${ }^{\circ}$ electrosprayed droplets of proteins in aqueous acetic acid had little effect on the appearance of the CSD. Addition of ammonium acetate to the solvent (as in the current experiments) enhanced lower $\mathrm{m} / \mathrm{z}$ ions, an effect explained by an increase in lifetime of the droplets allowing ${ }^{\circ}$ longer ${ }^{\circ}$ exposure ${ }^{\circ}$ f $^{\circ}$ the ${ }^{\circ}$ protein $^{\circ}$ to $^{\circ}$ heat ${ }^{\circ}[33]$.

The changes in the negative-ion spectra of lin- and to a lesser extent cz-DnaB-N(F102E) when the desolvation temperature was increased were not observed in

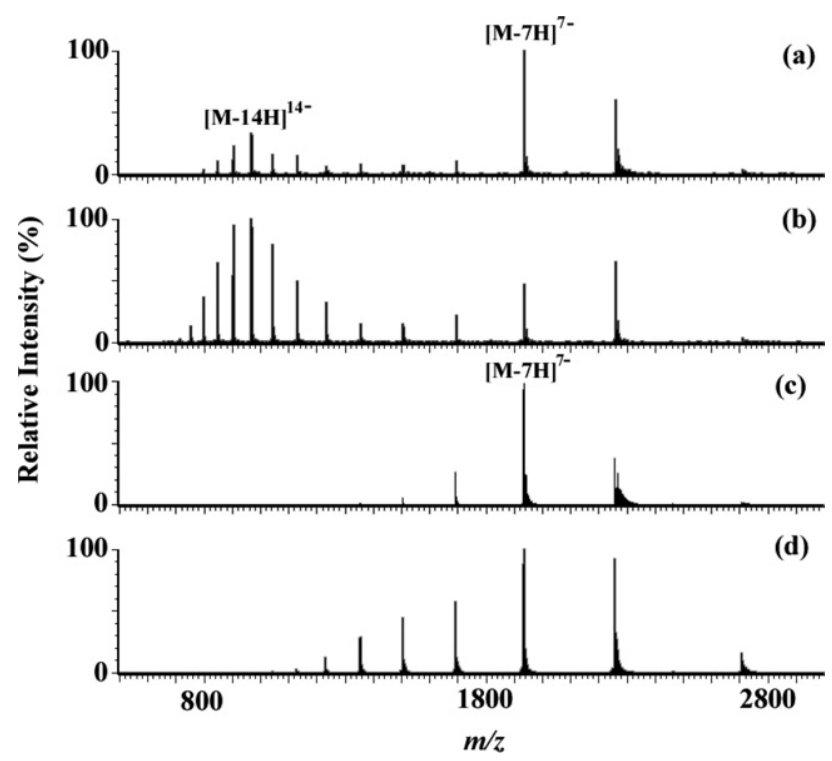

Figure 5. Negative-ion ESI mass spectra of lin-DnaB-N(F102E) and cz-DnaB-N(F102E) sprayed from $10 \mathrm{mM}$ ammonium acetate, $\mathrm{pH} 7.6$ using desolvation temperatures of 40 or $240^{\circ} \mathrm{C}$. (a) linDnaB-N(F102E) at $40^{\circ} \mathrm{C}$; (b) lin-DnaB-N(F102E) at $240{ }^{\circ} \mathrm{C}$; (c) cz-DnaB-N(F102E) at $40^{\circ} \mathrm{C}$; (d) cz-DnaB-N(F102E) at $240{ }^{\circ} \mathrm{C}$. 
positive-ion spectra. Discrepancies have been observed previously when assessing protein unfolding by changes in CSD of ESI mass spectra. The acid- and base-induced unfolding of ubiquitin and the acid-induced unfolding of cytochrome $\mathrm{c}$ were detected in positive-ion, but not negative-ion, ${ }^{\circ} \mathrm{ESI}^{\circ} \operatorname{mass}^{\circ} \operatorname{spectra}^{\circ}[31] .{ }^{\circ}$ Conformational changes of calmodulin on the binding of trifluoperazine detected by ESI mass spectrometry were evident as changes in the CSD in positive-ion, but not negativeion, ${ }^{\circ}$ mass $^{\circ}$ spectra $^{\circ}[24] .{ }^{\circ}$ Similarly, ${ }^{\circ}$ the ${ }^{\circ}$ results ${ }^{\circ}$ reported here suggest that negative-ion ESI mass spectrometry promotes unfolding of DnaB-N(F102E).

Figure $^{\circ} 6^{\circ}$ shows $^{\circ}$ the ${ }^{\circ}$ relative ${ }^{\circ}$ abundances ${ }^{\circ}$ of ${ }^{\circ}$ protein ions from the charge envelope representing the unfolded protein population (centered around the $13+$ or 14 - ions) in positive- and negative-ion ESI mass spectra over the accessible $\mathrm{pH}$ range (desolvation temperature $20{ }^{\circ} \mathrm{C}$ ). All the positive- and negative-ion ESI mass spectra of cz-DnaB-N(F102E) were similar to the spectra at $\mathrm{pH} 7.6$ with no unfolded protein present under any of the conditions (spectra not shown). There was a small increase in intensity of the $[\mathrm{M}-8 \mathrm{H}]^{8-}$ ion in the spectrum when the $\mathrm{pH}$ was 9.6 , but the $[\mathrm{M}-7 \mathrm{H}]^{7-}$ ion remained the most abundant in the spectrum. In both the positive and negative ESI mass spectra of lin-DnaB$\mathrm{N}(\mathrm{F} 102 \mathrm{E})$, the low abundance charge envelope from unfolded protein decreased as the $\mathrm{pH}$ was increased. In the negative-ion spectrum at $\mathrm{pH} 9.6$ the abundance of the $[\mathrm{M}-8 \mathrm{H}]^{8-}$ ion increased at $\mathrm{pH} 9.6$ as observed for the cyclized protein. This occurred in the absence of any ions from the charge envelope at lower $m / z$ (e.g., $[\mathrm{M}-14 \mathrm{H}]^{14-}$ ) and may reflect deprotonation of the

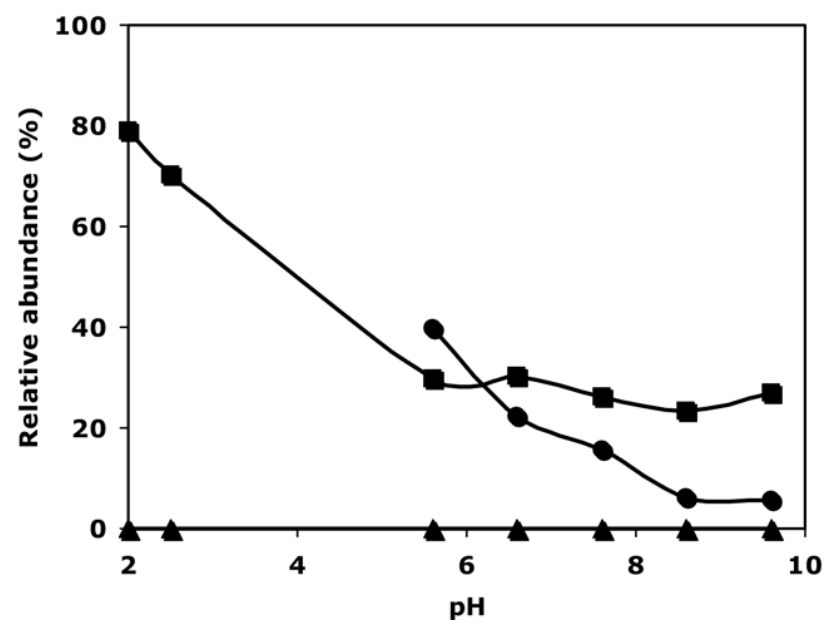

Figure 6. Relative abundances of unfolded forms of lin- and cz-DnaB-N(F102E) over the $\mathrm{pH}$ range 5.6 to 9.6 as represented by the abundances of ions in high and low $\mathrm{m} / \mathrm{z}$ charge envelopes in ESI mass spectra. The total intensity of ions from the low $\mathrm{m} / \mathrm{z}$ charge envelope was expressed as a percentage of the sum of intensities of all ions in the spectrum. It was not possible to obtain spectra over the $\mathrm{pH}$ range $3.5-5.5$ because the proteins are insoluble over this $\mathrm{pH}$ range. In addition, no negative-ion ESI mass spectra could be measured at $\mathrm{pH}$ 2.0. Lin-DnaB-N(F102E): positive ions $\boldsymbol{\square}$, negative ions $\bullet$. Cz-DnaB-N(F102E): positive and negative ions, $\boldsymbol{\Delta}$ amino terminus of the folded protein in solution at this $\mathrm{pH}$. The similarity of the relative abundances of the two charge envelopes in the positive- and negative-ion spectra of lin-DnaB-N(F102E), at each $\mathrm{pH}$ in the range 5.6 to 9.6 , is consistent with both ion modes detecting the same solution property (i.e., the greater extent of unfolding at lower $\mathrm{pH}$ ). The similar response for positive and negative ions with respect to $\mathrm{pH}$ stands in contrast to the effects observed with changing desolvation temperature where negative-ion spectra reported more unfolding with increasing temperature. The sensitivity to desolvation temperature may arise either from differences in ionization processes for negative compared with positive ions or from an intrinsic lower stability of negatively charged lin-DnaB-N(F102E) to temperature.

\section{Conclusions}

In vivo cyclization of DnaB-N(F102E) produced a protein [cz-DnaB-N(F102E)] stable to unfolding. As a result, the response of this protein to different solution and ionization conditions could be compared with its less stable linear counterpart [lin-DnaB-N(F102E)]: (i) under the same solution and instrumental conditions by decreasing the $\mathrm{pH}$, and (ii) in negative- and positive-ion ESI mass spectra using different desolvation temperatures. Both negative- and positive-ion ESI mass spectra revealed the presence of increased amounts of unfolded protein as the $\mathrm{pH}$ was decreased. In contrast, only negative-ion spectra revealed unfolding of this acidic protein as a result of an increase in desolvation temperature. The choice of polarity for acquisition of ESI mass spectra is therefore not always as simple as using negative-ion spectra for acidic proteins (and vice versa). The results illustrate the stability of cz-DnaB-N(F102E) under a wide range of conditions and highlight the importance of surveying a range of ESI-MS conditions for studies of proteins in different conformational states.

\section{Acknowledgments}

The authors thank the Australian Research Council, the Ramaciotti Foundation, University of Wollongong, and the Australian National University for financial support. SJW acknowledges an Australian Postgraduate Award. GO was the recipient of an Australian Research Council Federation Fellowship.

\section{References}

1. Chowdhury, S. K.; Katta, V.; Chait, B. T. Probing Conformational Changes in Proteins by Mass Spectrometry. J. Am. Chem. Soc. 1990, 112 9012-9013.

2. Loo, J. A.; Ogorzalek Loo, R. R.; Udseth, H. R.; Edmonds, C. G.; Smith, R. D. Solvent-induced Conformational Changes of Polypeptides Probed by Electrospray-Ionization Mass Spectrometry. Rapid Commun. Mass Spectrom. 1991, 5, 101-105.

3. Konermann, L.; Douglas, D. J. Equilibrium Unfolding of Proteins Monitored by Electrospray Ionization Mass Spectrometry: Distinguishing Two-State from Multi-State Transitions. Rapid Commun. Mass Spectrom. 1998, 12, 435-442. 
4. Dobo, A.; Kaltashov, I. A. Detection of Multiple Protein Conformational Ensembles in Solution via Deconvolution of Charge-State Distributions in ESI MS. Anal. Chem. 2001, 73, 4763-4773.

5. Gumerov, D. R.; Dobo, A.; Kaltashov, I. A. Protein-Ion Charge-State Distribution in Electrospray Ionization Mass Spectrometry: Distinguishing Conformational Contributions from Masking Effects. Eur. J. Mass Spectrom. 2002, 8, 123-129.

6. Samalikova, M.; Matecko, I.; Muller, N.; Grandori, R. Interpreting Conformational Effects in Protein Nano-ESI-MS Spectra. Anal. Bioanal. Chem. 2004, 378, 1112-1123.

7. Covey, T. R.; Bonner, R. F.; Shushan, B. I.; Henion, J.; Boyd, R. K. The Determination of Protein, Oligonucleotide and Peptide Molecular Weights by Ion-Spray Mass Spectrometry. Rapid Commun. Mass Spectrom. 1988, 2, 249-256.

8. Loo, J. A.; Edmonds, C. G.; Udseth, H. R.; Smith, R. D. Effect of Reducing Disulfide-containing Proteins on Electrospray Ionization Mass Spectra. Anal. Chem. 1990, 62, 693-698.

9. Fenn, J. B. Ion Formation from Charged Droplets: Roles of Geometry, Energy, and Time. J. Am. Soc. Mass Spectrom. 1993, 4, 524-535.

10. de la Mora, J. F. Electrospray Ionization of Large Multiply Charged Species Proceeds via Dole's Charged Residue Mechanism. Anal. Chim. Acta 2000, 406, 93-104.

11. Nesatyy, V. J.; Suter, M. J.-F. On the Conformation-dependent Neutralization Theory and Charging of Individual Proteins and Their Noncovalent Complexes in the Gas Phase. J. Mass Spectrom. 2004, 39, 93-97.

12. Kelly, M. A.; Vestling, M. M.; Fenselau, C. C.; Smith, P. B. Electrospray Analysis of Proteins: A Comparison of Positive-Ion and Negative-Ion Mass Spectra at High and Low pH. Org. Mass Spectrom. 1992, 27, 1143-1147.

13. Zhang, L.; Zhang, F.; Zhang, S.-Y.; Guo, Y.-L.; Xu, C.-H. Acetonitrileinduced Unfolding of the Photosystem II Manganese-stabilizing Protein Studied by Electrospray Mass Spectrometry. Rapid Commun. Mass Spectrom. 2005, 19, 2151-2156.

14. Cech, N. B; Enke, C. G. Practical Implications of Some Recent Studies in Electrospray Ionization Fundamentals. Mass Spectrom. Rev. 2001, 20, 362-387.

15. Iribarne, J. V.; Thomson, B. A. On the Evaporation of Small Ions from Charged Droplets. J. Chem. Phys. 1976, 64, 2287-2294.

16. Dole, M.; Mack, L. L.; Hines, R. L.; Mobley, R. C.; Ferguson, L. P.; Alice, M. B. Molecular Beams of Macroions. J. Chem. Phys. 1968, 49, 2240-2249.

17. Kebarle, P. A Brief Overview of the Present Status of the Mechanisms Involved in Electrospray Mass Spectrometry. J. Mass Spectrom. 2000, 35 , 804-817.

18. Amad, M. H.; Cech, N. B.; Jackson, G. S.; Enke, C. G. Importance of Gas-Phase Proton Affinities in Determining the Electrospray Ionization Response for Analytes and Solvents. J. Mass Spectrom. 2000, 35, 784-789.

19. Iavarone, A. T.; Jurchen, J. C.; Williams, E. R. Effects of Solvent on the Maximum Charge State and Charge State Distribution of Protein Ions Produced by Electrospray Ionization. J. Am. Soc. Mass Spectrom. 2000, 11, 976-985.
20. Verkerk, U. H.; Kebarle, P. Ion-Ion and Ion-Molecule Reactions at the Surface of Proteins Produced by Nanospray. Information on the Number of Acidic Residues and Control of the Number of Ionized Acidic and Basic Residues. J. Am. Soc. Mass Spectrom. 2005, 16, 1325-1341.

21. Simmons, D. A.; Konermann, L. Characterization of Transient Protein Folding Intermediates during Myoglobin Reconstitution by TimeResolved Electrospray Mass Spectrometry with On-line Isotopic Pulse Labeling. Biochemistry 2002, 41, 1906-1914.

22. Loo, J. A.; Edmonds, C. G.; Udseth, H. R.; Smith, R. D. Effect of Reducing Disulfide-containing Proteins on Electrospray Ionization Mass Spectra. Anal. Chem. 1990, 62, 693-698.

23. Veenstra, T. D.; Johnson, K. L.; Tomlinson, A. J.; Naylor, S.; Kumar, R. Electrospray Ionization Mass Spectrometry Temperature Effects on Metal Ion:Protein Stoichiometries and Metal-induced Conformational Changes in Calmodulin. Eur. Mass Spectrom. 1997, 3, 453-459.

24. Watt, S. J.; Oakley, A.; Sheil, M. M.; Beck, J. L. Comparison of Negative and Positive Ion Electrospray Ionization Mass Spectra of Calmodulin and Its Complex with Trifluoperazine. Rapid Commun. Mass Spectrom. 2005, 19, 2123-2130.

25. Weigelt, J.; Brown, S. E.; Miles, C. S.; Dixon, N. E.; Otting, G. NMR Structure of the N-Terminal Domain of E. coli DnaB Helicase: Implications for Structure Rearrangements in the Helicase Hexamer. Structure 1999, 7, 681-690.

26. Williams, N. K.; Liepinsh, E.; Watt, S. J.; Prosselkov, P.; Matthews, J. M.; Attard, P.; Beck, J. L.; Dixon, N. E.; Otting, G. Stabilization of Native Protein Fold by Intein-mediated Covalent Cyclization. J. Mol. Biol. 2005 346, 1095-1108.

27. Deechongkit, S.; Kelly, J. W. The Effect of Backbone Cyclization on the Thermodynamics of $\beta$-Sheet Unfolding: Stability Optimization of the PIN WW Domain. J. Am. Chem. Soc. 2002, 124, 4980-4986.

28. Williams, N. K.; Prosselkov, P.; Liepinsh, E.; Line, I.; Sharipo, A.; Littler, D. R.; Curmi, P. M. G.; Otting, G.; Dixon, N. N. In Vivo Protein Cyclization Promoted by a Circularly Permuted Synechocystis sp. PCC6803 DnaB Mini-Intein. J. Biol. Chem. 2002, 277, 7790-7798.

29. Zhou, H.-X. Effect of Backbone Cyclization on Protein Folding Stability: Chain Entropies of Both the Unfolded and the Folded States Are Restricted. J. Mol. Biol. 2003, 332, 257-264.

30. Camarero, J. A.; Fushman, D.; Sato, S.; Giriat, I.; Cowburn, D.; Raleigh, D. P.; Muir, T. W. Rescuing a Destabilized Protein Fold through Backbone Cyclization. J. Mol. Biol. 2001, 308, 1045-1062.

31. Konermann L.; Douglas, D. J. Unfolding of Proteins Monitored by Electrospray Ionization Mass Spectrometry: A Comparison of Positive and Negative Ion Modes. J. Am. Soc. Mass Spectrom. 1998, 9, 1248-1254.

32. Fass, D.; Bogden, C. E.; Berger, J. M. Crystal Structure of the N-Terminal Domain of the DnaB Hexameric Helicase. Structure 1999, 7, 691-698.

33. Mirza, U. A.; Chait, B. T. Do Proteins Denature during Droplet Evolution in Electrospray Ionization? Int. J. Mass Spectrom. Ion Process. 1997, 162, 173-181. 